\title{
Exploration of Non-compliance of Micro, Small and Medium Business Taxpayers: Phenomenology Study
}

\author{
Umi Nandiroh \\ uminandiroh@unisma.ac.id \\ Universitas Islam Malang
}

\begin{abstract}
This study aims to describe the meaning of non-compliance with taxes, especially for taxpayers of small and medium enterprises. The background of this research is that there is a phenomenon that is not all taxpayers' fulfill their tax obligations in accordance with the provisions of tax regulations. Resistance that occurs in carrying out tax obligations depends on how tax interpreters interpret noncompliance. This study used a qualitative approach with the Schutz interpretive phenomenology as a research method. The phenomenology method focuses on the object of exploration to gain knowledge. Data was obtained through interviews with small business taxpayers. This study found the motives of taxpayers in carrying out their tax obligations. Which consisted of six elements, namely: situations those were dilematic, opportunistic, distrust, injustice, not willing, and saving yourself. The motive must be found first, because based on Schutz's interpretive phenomenologymethod, someone will interpret something depending on the motive in interpreting something. From the motives that have been known, it can be concluded that in order to carry out their tax obligations, taxpayers need trust, both for the government, and for God.
\end{abstract}

Keywords : Non-Compliance; Phenomenology; Small Business Taxpayers.

\section{INTRODUCTION}

Tax is a compulsory contribution to the state owed by an individual, or a coercive body based on the Law, by not getting compensation directly and used for state needs for the greatest prosperity of the people (DGT, 2007). In Indonesia, taxes are the main source in the State Budget (APBN), to finance government spending and development. In order to carry out the functions of government management properly, there is a need for substantial state revenues. Thus, the achievement of planned development goals for people's welfare will be more easily realized (Lubis, 2015).

Given tax revenue as the main source in the implementation of government and state development, it is only natural that there is an increase in the target of tax 
JEMAP: Jurnal Ekonomi, Manajemen, Akuntansi, dan Perpajakan

ISSN: 2622-612X (Media Online) | Vol.4 | No.2 | Oktober 2021

revenues, along with the increasing expenditure requirements. The following is the target data and realization of tax revenues over the past four years.

Table 1. Realization of Tax Revenue

\begin{tabular}{|l|r|r|r|r|}
\hline \multicolumn{1}{|c|}{ Year } & \multicolumn{1}{c|}{$\mathbf{2 0 1 3}$} & \multicolumn{1}{c|}{$\mathbf{2 0 1 4}$} & \multicolumn{1}{c|}{$\mathbf{2 0 1 5}$} & \multicolumn{1}{c|}{$\mathbf{2 0 1 6}$} \\
\hline Target & $995.21 \mathrm{~T}$ & $1,072.37 \mathrm{~T}$ & $1,294.26 \mathrm{~T}$ & $1355.20 \mathrm{~T}$ \\
\hline Realization & $921.27 \mathrm{~T}$ & $981.83 \mathrm{~T}$ & $1,060.83 \mathrm{~T}$ & $1105.81 \mathrm{~T}$ \\
\hline Achievements & $92.57 \%$ & $91.56 \%$ & $81.96 \%$ & $81.60 \%$ \\
\hline Year & $\Delta 2013-2014$ & \multicolumn{2}{|c|}{$\Delta 2014-2015$} & $\Delta 2015-2016$ \\
\hline Growth & $6.92 \%$ & \multicolumn{2}{|c|}{$7.68 \%$} & $4.24 \%$ \\
\hline
\end{tabular}

Source: Directorate General of Tax (DJP) Performance Report (LAKIN) in 2016

It cannot be denied that the level of tax revenue is directly proportional to the level of tax compliance. Because in Indonesia, taxes are derived from community contributions (taxpayers) using the self system assement. Self system The assessment is one of the tax reform agenda that has been carried out by the government in 1998. The self system assessment is a tax collection system that gives authority, trust, and responsibility to taxpayers to calculate, calculate, deposit, and self-report taxes that must be paid. Unlike the previous system, the official system assessment which is a tax collection system that authorizes the government to determine the amount of tax payable (Waluyo, 2014, p. 17). For this reason, the low level of compliance is suspected to be one of the causes of low tax revenues. Regarding the issue of taxpayer compliance, the DGT's 2016 Performance Report has documented a portrait of taxpayer compliance as follows;

Table 2. Compliance Ratio for submitting Annual Income Tax Returns for 2013 to 2016

\begin{tabular}{|l|c|c|c|c|}
\hline \multicolumn{1}{|c|}{ Year } & $\mathbf{2 0 1 3}$ & $\mathbf{2 0 1 4}$ & $\mathbf{2 0 1 5}$ & \multirow{2}{*}{$\mathbf{2 0 1 6}$} \\
\cline { 1 - 5 } Rescription & & & & \\
\hline Tax Payer Registered Taxpayer & $24,347,763$ & $27,379,256$ & $30,044,103$ & $32,769,215$ \\
\hline Target Compliance Ratio (\%) & $17,731,736$ & $18,357,833$ & $18,159,840$ & 20.165 .718 \\
\hline Target SPT Compliance Ratio & $65.00 \%$ & $70.00 \%$ & $70.00 \%$ & $72.50 \%$ \\
\hline Realization of SPT & $11,525,628$ & 12.82 .301 & $12,711,888$ & $14,620,146$ \\
\hline Compliance ratio & $9,966,833$ & $10,852,301$ & $10,972,336$ & $12,735,463$ \\
\hline Achievement of the Compliance Ratio & $56.21 \%$ & $59.12 \%$ & $60.42 \%$ & $63.15 \%$ \\
\hline
\end{tabular}

Source: DGT Performance Report 2016 
JEMAP: Jurnal Ekonomi, Manajemen, Akuntansi, dan Perpajakan

ISSN: 2622-612X (Media Online) | Vol.4 | No.2 | Oktober 2021

Imaniati (2016) suggests that taxpayer compliance in Indonesia is still low. One of the causes of the low ratio of tax revenues in Indonesia is the low compliance with tax compliance. Furthermore, Imaniati revealed, in recent years tax revenues were still low not only national tax revenues were not optimal but the tax ratio also decreased. Tax receipts that do not reach the target indicate a low level of tax compliance. Tax compliance is defined as a condition in which taxpayers fulfill all tax obligations and carry out their taxation rights, in accordance with the provisions of the Law (Hanefah, Ariff, \& Kasipillai, 2014).

To achieve the tax revenue target, the DGT continues to optimize various potential taxes, including the Micro, Small and Medium Enterprises (MSME) sector. MSMEs are economic sectors that have a considerable role in the national economy. Of course we still remember the devastation of the national economy during the 1998 economic crisis. UMKM came as a savior of the nation with its long breath through sustainable business activities so that it could still absorb labor. Even though at the same time large businesses fall. As a result, unemployment can be minimized by MSME actors.

However, making the MSME sector a target for tax optimization is not an easy matter. Because the contribution of MSMEs to tax revenues is still far behind compared to the contribution of MSMEs to gross domestic product (GDP). Based on 2015 GDP data, MSMEs contribute approximately 57\% of total GDP. However, when compared with the contribution of MSMEs to tax revenues, there are still gaps, where the contribution of MSMEs to tax revenues is still very small, which is approximately $0.5 \%$ of total tax revenues. The imbalance in the contribution of MSMEs is an indication that the level of compliance of MSMEs in fulfilling their tax obligations is still very low (www.citraindonesia.com , 2015).

The low compliance of taxable MSMEs is suspected by several factors. Namely knowledge of taxation, awareness of taxpayers, taxation sanctions (Hendri, 2016), perceptions of taxpayers (Imaniati, 2016), interpretation of taxpayers (Mutiah, Harwida, \& Kurniawan, 2011), and level of understanding of taxpayers (Mukaromah, 2012). 
JEMAP: Jurnal Ekonomi, Manajemen, Akuntansi, dan Perpajakan

ISSN: 2622-612X (Media Online) | Vol.4 | No.2 | Oktober 2021

In Indonesia the tax collection system applied is self assessment. Which, with this system requires taxpayers to carry out their own tax obligations, starting from calculating the amount of tax to be paid, paying the tax, and reporting it. This of course demands independence, as well as the active role of taxpayers, which is precisely the problem starting here. Instead of fulfilling tax obligations that are so complex, the problem of calculating the amount of tax payable has become a problem for MSME taxpayers. Persoalan her, they were not used to keep records or books in its business operations. Even though this recording is the basis for tax calculation. The existence of good bookkeeping can also increase taxpayer compliance due to limited resources allegedly to be the cause of the absence of recording and bookkeeping in MSME operations. Often MSME players are unable to recruit professional bookkeepers to support tax compliance, so orderly administration through good bookkeeping is not a top priority with regard to the efficiency of costs to be incurred (Rohman, Zulaikha, Raharjo, \& Harto, 2011).

Responding to the difficulties of taxpayers in carrying out their tax obligations, caused by the complexity of tax regulations, the government issued a 2013 Government Regulation on Income Tax on Income from Businesses Received or Obtained by Taxpayers with Certain Gross Circulation (PP 46). This regulation regulates individual entrepreneurs or non-Permanent Entity entities with no gross circulation of more than 4.8 billion per year, subject to a tariff of $1 \%$. The policy is expected to educate the public for orderly administration (Anjani \&Restuti, 2016).

However, the implementation of PP 46 is not necessarily able to increase the level of compliance of MSME taxpayers as expected. A-alih cf. simplify tax laws, the application of Regulation 46 actually reap a lot of controversy. The response was quite strong coming from Sari economic observer (2013) who claimed that PP 46 was unfair, because it also imposes a tax on the loss of MSME players. The same thing was expressed by Aneswari et al (2016) that PP 46 had ignored Taxable Income (PTKP) which is the right of individual taxpayers.

The disobedience of MSMEs in fulfilling their tax obligations is still a complicated issue, so it is interesting to study more deeply. Given the unique characteristics of MSMEs, MSMEs are also a strong sector in facing various 
JEMAP: Jurnal Ekonomi, Manajemen, Akuntansi, dan Perpajakan

ISSN: 2622-612X (Media Online) | Vol.4 | No.2 | Oktober 2021

economic conditions. PP 46 whose purpose is to simplify tax administration for MSMEs, and is expected to be an accurate solution to overcome noncompliance MSMEs, but the reality does not further improve the problems that exist, instead it raises many protests from the public. Does the issue of MSMEs only lie in the complexity of tax regulations? Or there are other things behind it. This is what makes researchers interested in conducting a more in-depth study, about the phenomenon of non-compliance of MSME taxpayers in fulfilling their tax obligations. As a differentiator from previous research, this study focuses on the meaning of non-compliance of MSME taxpayers, based on the experience of taxpayers. Not just looking at the empirical side of a taxpayer's disobedience.

\section{METHOD}

However, making the MSME sector a target for tax optimization is not an easy matter. Because the contribution of MSMEs to tax revenues is still far behind compared to the contribution of MSMEs to gross domestic product (GDP). Based on 2015 GDP data, MSMEs contribute approximately 57\% of total GDP. However, when compared with the contribution of MSMEs to tax revenues, there are still gaps, where the contribution of MSMEs to tax revenues is still very small, which is approximately $0.5 \%$ of total tax revenues. The imbalance in the contribution of MSMEs is an indication that the level of compliance of MSMEs in fulfilling their tax obligations is still very low (www.citraindonesia.com, 2015).

The low compliance of taxable MSMEs is suspected by several factors. Namely knowledge of taxation, awareness of taxpayers, taxation sanctions (Hendri, 2016), perceptions of taxpayers (Imaniati, 2016), interpretation of taxpayers (Mutiah, Harwida, \& Kurniawan, 2011), and level of understanding of taxpayers (Mukaromah, 2012).

In Indonesia the tax collection system applied is self assessment. Which, with this system requires taxpayers to carry out their own tax obligations, starting from calculating the amount of tax to be paid, paying the tax, and reporting it. This of course demands independence, as well as the active role of taxpayers, which is precisely the problem starting here. Instead of fulfilling tax obligations that are so 
complex, the problem of calculating the amount of tax payable has become a problem for MSME taxpayers. Persoalan her, they were not used to keep records or books in its business operations. Even though this recording is the basis for tax calculation. The existence of good bookkeeping can also increase taxpayer compliance due to limited resources allegedly to be the cause of the absence of recording and bookkeeping in MSME operations. Often MSME players are unable to recruit professional bookkeepers to support tax compliance, so orderly administration through good bookkeeping is not a top priority with regard to the efficiency of costs to be incurred (Rohman, Zulaikha, Raharjo, \& Harto, 2011).

Responding to the difficulties of taxpayers in carrying out their tax obligations, caused by the complexity of tax regulations, the government issued a 2013 Government Regulation on Income Tax on Income from Businesses Received or Obtained by Taxpayers with Certain Gross Circulation (PP 46). This regulation regulates individual entrepreneurs or non-Permanent Entity entities with no gross circulation of more than 4.8 billion per year, subject to a tariff of $1 \%$. The policy is expected to educate the public for orderly administration (Anjani \& Restuti, 2016).

However, the implementation of PP 46 is not necessarily able to increase the level of compliance of MSME taxpayers as expected. A-alih cf. simplify tax laws, the application of Regulation 46 actually reap a lot of controversy. The response was quite strong coming from Sari economic observer (2013) who claimed that PP 46 was unfair, because it also imposes a tax on the loss of MSME players. The same thing was expressed by Aneswari et al (2016) that PP 46 had ignored Taxable Income (PTKP) which is the right of individual taxpayers.

The disobedience of MSMEs in fulfilling their tax obligations is still a complicated issue, so it is interesting to study more deeply. Given the unique characteristics of MSMEs, MSMEs are also a strong sector in facing various economic conditions. PP 46 whose purpose is to simplify tax administration for MSMEs, and is expected to be an accurate solution to overcome noncompliance MSMEs, but the reality does not further improve the problems that exist, instead it raises many protests from the public. Does the issue of MSMEs only lie in the complexity of tax regulations? Or there are other things behind it. This is 
JEMAP: Jurnal Ekonomi, Manajemen, Akuntansi, dan Perpajakan

ISSN: 2622-612X (Media Online) | Vol.4 | No.2 | Oktober 2021

what makes researchers interested in conducting a more in-depth study, about the phenomenon of non-compliance of MSME taxpayers in fulfilling their tax obligations. As a differentiator from previous research, this study focuses on the meaning of non-compliance of MSME taxpayers, based on the experience of taxpayers. Not just looking at the empirical side of a taxpayer's disobedience.

\section{RESULT AND DISCUSSION}

\section{Revealing "Because Motive" Tax Non-compliance}

Phenomenology research departs from a perspective that human experiences are a source of knowledge because experience is a collection of human consciousness that is expressed through human actions that aim in accordance with human desires themselves. These experiences are then represented through a conseptual meaning.

Inspired by Schutz's phenomenology, which explores subjective meanings with the concept of causal relationships so that it truly finds the original original motives of individual actions. According to Schutz, the context of meaning can come to the surface when humans look back, review and select the characteristics of the situation before the action is taken and consider it as the reason or the reason why the action was carried out. Schutz emphasizes that the meaning can be labeled with a behavior by looking back at what preceded the action, even though the researcher did not experience it actually. Thus, from the presentation of taxpayer intentionality, researchers will identify the motives underlying these actions, known as because of motives. The following are described several things that are due to themotives in the non-compliance of informants' taxpayers:

\section{Tax Non-compliance due to Dilemma}

This research has identified situations that place taxpayers in a condition of dilemma, that is, when taxpayers must carry out their own tax obligations on Self Assessment with existing limitations, namely knowledge of tax provisions that are minimal and unfriendly with company business, behavior negative tax officers, the benefits of paying taxes that have not been felt. The following is a quote from the informant's statement: 
"... I have never used my TIN, to report my income tax. I don't know, I really don't know ..."

"... after I established the $C V$, it was only later that I learned that tax regulations were complex and difficult to understand."

"In our country this is a tax to finance the government, he said, but when access to public services still pays right? For example taking care of a letter, it's still paying. That then makes us doubt, why pay taxes?"

Simultaneously, these situations allow taxpayers to get motivation as well as sanctions. Motivation is related to tax planning efforts that can benefit taxpayers, but on the other hand taxpayers are also faced with the consequences that taxes are levies regulated under the provisions of tax laws so as to provide consequences for sanctions for every taxpayer's resistance.

Dilemma taxpayers in the view of Alm, et al (2012) is a situation where the taxpayer is in doubt because the decision to comply with or not comply with the provisions of the tax law can conflict with the interests of himself or the community. Dilemma in the view of Parks and Vu (1994) illustrates a conflict of interest between personal interests and collective interests. Two expert views above concerning the concept of a dilemma has positioned someone in a decision making situation whether to sacrifice collective interests or maximize individual interests.

\section{Tax Non-compliance Due to Opportunities}

Various efforts have been made by the government through DGT to improve taxpayer compliance including replacing the tax collection system from the Official Assessment system which relies on the activity of tax officers to calculate the tax payable, into a Self Assessment that relies on the independence of taxpayers in calculating, paying and reporting taxes owed with awareness and upholding the principle of integrity. Through self assessment, the government gives great trust to taxpayers to be responsible in carrying out their tax obligations independently and prioritize aspects of integrity, voluntary and without coercion. Therefore, the description of the Self Assessment system is a representation of a belief, awareness, honesty, and independence (Mangoting, 2016). 
Self Assessment has a fundamental weakness that this system can be used as an opportunity for taxpayers to make an engineering payment of taxes as large as tax savings desired by taxpayers (Kartini, Yuniarta, \& Sujana, 2017). This can be proven from the data found in the field that there are efforts to save tax in ways that are not in accordance with the provisions of the tax law. In addition to these methods, the data in the field also speaks that there are injustices in Self Assessment experienced by taxpayers, for example the provisions of complex tax laws, making it difficult for taxpayers to understand, coupled with the lack of socialization and education support from tax officials. This lack of understanding can cause taxpayers to make mistakes in calculating the tax payable.

\section{Non-compliance with taxes due to distrust of taxpayers}

In the context of this research, taxpayers will develop trust if they have sufficient references and experience gained in the tax system environment to build trust as their basis for acting or responding. Elements in the taxation system such as taxation provisions are simple and easy to implement, taxation policies that favor taxpayers, tax officers with professionalism and primitive service independence, benefits of tax payments, and other taxpayer non-compliance behaviors are impulses to taxpayers to form trust in the government so that it can carry out tax obligations in accordance with the provisions of the tax law.

This imbalance between tax rights and obligations forms the distrust of taxpayers. The facts gathered in the field actually prove the existence of distrust of the taxpayer to the DGT, because of several situations that accompanied. The situation is a complex tax regulation that is not friendly to taxpayers' business, unilateral mastery of information because tax officials have not provided adequate information and education to taxpayers regarding the provisions of tax laws, and weak law enforcement because tax officers do not take action against taxpayers who do not carry out their tax obligations in accordance with the provisions of tax laws.

\section{Tax Non-compliance Due to Injustice}

Injustice revealed in the facts on the ground can move from a taxpayer rationality idea. Ross (2004) explained that the people generally would not rebel if the government raised tax rates as long as the increase in tax rates was used to create 
JEMAP: Jurnal Ekonomi, Manajemen, Akuntansi, dan Perpajakan

ISSN: 2622-612X (Media Online) | Vol.4 | No.2 | Oktober 2021

adequate public facilities and infrastructure. Even Ross further explained that the people would not object if the government raised the tax rate unilaterally without going through parliament as long as the taxes they paid were commensurate with the benefits they would receive.

Basically there are efforts by taxpayers to associate their tax non-compliance with the government's failure to fulfill contracts between the state and taxpayers so as to cause injustice. The government requires tax obligations to be carried out but does not provide rights that taxpayers should obtain. This injustice is reflected in the high number of corruption cases, poor public services, accountability and transparency in the management of low public finances, and high economic costs.

\section{Tax Non-compliance Due to Unwillingness to Pay Taxes}

Willingness in KBBI means willingness or approval, the opposite of willingness is unwillingness which means unwilling or not willing. Disability of taxpayers means that taxpayers pay less than taxes that should be paid or taxpayers do not pay at all. In the context of this study, the government needs to be aware that taxpayers are ordinary people who consider selfishness to be rational. Including when taxpayers see that their tax payments have been misused by public officials who should be responsible for managing public funds and making them happen through public facilities and infrastructures. The above conditions create the unwillingness of the taxpayer to pay taxes but the taxpayer is not likely to avoid the tax obligations, so he decides to pay but not in accordance with the provisions of the tax law.

"In our country this is a tax to finance the government, he said, but when access to public services still pays right? For example taking care of a letter, it's still paying. That then makes us doubt, why pay taxes?"

Taxpayer informants understand that as citizens they have the obligation to pay taxes. In addition, he also understands that taxes function as state revenues that are fully used to finance the implementation of development. But on the other hand, taxpayer informants feel that the money they collect is in the form of tax payments, the benefits have not yet been felt to their full potential so taxpayer informants then question the extent to which the tax payments they have deposited 
JEMAP: Jurnal Ekonomi, Manajemen, Akuntansi, dan Perpajakan

ISSN: 2622-612X (Media Online) | Vol.4 | No.2 | Oktober 2021

to the state are used to finance the procurement of facilities and infrastructure for public interest. Taxpayer informants through the statement above also questioned the weak performance of government accountability in managing public funds.

Hasseldine and Bebingtone (1991) emphasize that the loss of motivation from taxpayers to pay taxes because there is no real benefit from the benefits of paying taxes. If taxes paid and public services provided by the government are considered by taxpayers evenly distributed, taxpayers may tend to comply with tax laws and this has a positive effect.

\section{Tax Non-compliance is a Self-Saving Effort}

In the context of this research, taxpayers carry out a denial, negation or attempt to save themselves from taxpayer mistakes. Denial or omission is the effort of the taxpayer to save themselves or move their mistakes and throw the error to the DGT because the taxpayer considers DGT has not prepared a conducive environment for the implementation of Self Assessment. Taxpayers say do not change taxpayers if the behavior of tax officials has not changed or why they must comply if other taxpayers do not comply or why they must comply if what we pay is misused for the personal interests of individual tax officers or other public officials.

Taxpayers assume that they should not be blamed for the non-compliance of taxes they do, for example by manipulating sales to reduce Final $\mathrm{PPh}$ payments, not reporting all assets owned, or not paying taxes at all, not solely because of the taxpayer's wishes but because unsupportive situation.

Taxpayers try to transfer errors to DGT and the government and even other taxpayers. They consider that non-compliance is done because they do not get their rights as taxpayers, for example the right to complete information relating to the provisions of tax laws, the right to benefit from paying taxes, because taxpayers find corruption committed by individual public officials can reduce the public benefits they should receive as compensation for paying their taxes.

\section{Taxpayers Need " Vitamin $C$ "}

In one of the discussions held by the Indonesian Business Forum, Justin Prastowo commented " whatever efforts have been made by the government, 
JEMAP: Jurnal Ekonomi, Manajemen, Akuntansi, dan Perpajakan

ISSN: 2622-612X (Media Online) | Vol.4 | No.2 | Oktober 2021

actually taxpayers only need 'vitamin $C^{\prime}$ Confidance, so the current homework of the government is, how to provide vitamin C intake ". Relevant to the statement, this study has found that indeed taxpayer trust is crucial. From the results of interviews with informants, researchers summarize there are two 'beliefs' that lie behind taxpayers in carrying out tax obligations, namely trust in the government, and trust in God.

1. Non-compliance of taxpayers, due to distrust of taxpayers to the government

"In our country this is a tax to finance the government, he said, but when access to public services still pays right? For example taking care of a letter, it's still paying. That then makes us doubt, why pay taxes?"

Thus the taxpayer's comments, related to the perceived benefits of paying taxes. Taxpayers feel that the state has forced people to fulfill their tax obligations, while the state has never been fair in providing good social services to the people. Again, taxpayers demand the benefit of paying taxes that can be felt directly.

This study reflects that the obligation to pay taxes has formed a state commitment for taxpayers, namely the commitment to provide services that guarantee taxpayers can carry out their tax obligations properly, and commitment that taxpayers can benefit from paying the tax through the creation of shared welfare as has been stated in the Opening of the 1945 Constitution.

In qualitative research, reality is a fact that describes events or events experienced by someone in a world of life. This fact was revealed by the informants of this study that non-compliance in carrying out tax obligations was associated with two things, namely: firstly related to the lack of knowledge of taxation, which was caused by a lack of socialization and education from tax officers. Second, the benefits of paying taxes that have not been felt, through the adequacy of public facilities and infrastructure. These two things ultimately erode the trust of taxpayers to the government.

\section{Social Realities and Spiritual Landscapes}

Indonesia is a country that upholds religiosity, this is evidenced by putting Godhead as the first principle as the basis of the Panggabean state (2014, p. 42). The first precept of Pancasila means that the other precepts must be based on divine 
JEMAP: Jurnal Ekonomi, Manajemen, Akuntansi, dan Perpajakan

ISSN: 2622-612X (Media Online) | Vol.4 | No.2 | Oktober 2021

values. Therefore, the values of Godhead rooted in religious teachings are very close in the lives of Indonesian people. The religious values embraced by the community are expected to prevent negative attitudes and encourage positive attitudes in everyday life. The findings of this study have proven this hope.

"As Muslims, there is an order that we must obey UlilAmri, now UlilAmri is here, the president. Therefore, I must obey the rules made by the president. As a good Muslim, obedient servant, I must obey all the rules made by the government, including those taxes earlier. "

From the statement of the informant, illustrates that trust in God (faith) has encouraged taxpayers to comply with the Law, namely implementing tax obligations. With all the limitations of the knowledge possessed by informants, as well as a lack of trust in the government, the informants still want to carry out tax obligations.

The results of this study are in line with several studies abroad about the value of religiosity influencing the behavior of taxpayer compliance, such as Torgler (2002) and Welch (1991), and Pope (2012). Religiosity comes from the noble religious values of the Almighty God who teaches honesty and integrity behavior towards each follower (Panggabean, 2014 ). Mohdali (2013) mentioning the existence of the role of religious values, is expected to spur positive behavior and prevent negative behavior towards tax compliance so as to encourage increased compliance behavior of taxpayers.

\section{CONCLUSION}

Taxpayers in this study provide an illustration that tax disobedience is not solely triggered by the personal desire of taxpayers to maximize utility as well as in the approach of Fiscal Psychology Theory. Through Home Visits Psychology, Fiscal consider the expectation of utilities (expected utility) to be received by the taxpayer. If the taxpayer does not perform tax obligations, the risks of noncompliance can be detected.

From the explanation or explanation above, this study concludes that the meaning of tax non-compliance departs from the violation of rights that should be 
JEMAP: Jurnal Ekonomi, Manajemen, Akuntansi, dan Perpajakan

ISSN: 2622-612X (Media Online) | Vol.4 | No.2 | Oktober 2021

received by taxpayers in a tax collection system based on Self Assessment. Violation to government commitments relates to the benefits of tax payments and to accountability in managing public funds, and to the uncertainty felt by taxpayers in carrying out their tax obligations.

In the context of tax non-compliance, the economic perspective is not enough to be a single motivation. Therefore, this study produced six elements, as "reasonedmotive" of taxpayers non-compliance. Namely: dilemmatic situations, opportunities, distrust, injustice, unwillingness, and efforts to save oneself. These six elements are the results of the exposure of taxpayer intention, as a result of the interaction of taxpayers with their social environment.

In fulfilling tax obligations, it is very necessary to need "vitamin C", which is Confidence. The first trust is the trust of taxpayers to the government, where this arises from the perception of taxpayers on the government. The second belief is trust in God (moral religion). To be an obedient taxpayer besides trusting the government, also trusting God (aspects of religiosity). From the results of some researches, it has been found that belief in God is able to make taxpayers to want to carry out their tax obligations. Therefore, in order to increase tax revenues from taxpayers, the DGT is expected to be able to use the element of religious motives or reasons. The Directorate General Taxation can cooperate with religious leaders and organizations to encourage taxpayers to be more obedient to tax regulations.

\section{DAFTAR PUSTAKA}

Alm, J., Kirchler, \& Muehlbacher. (2012). Combining psychology and economics in the analysis of compliance: From enforcement to cooperation. Economic Analysis \& Policy, 42 (2), 133-155.

Aneswari, YR, Darmayasa, IN, \& Yusdita, EE (2016). Critical perspective for implementing $1 \%$ income tax on msmes. Published manuscript, Malang.

Anjani, DN, \& Restuti, MMD (2016). Analysis of factors of individual taxpayer compliance with business actors at primary tax office in Salatiga. Indonesian Accounting and Finance Period, 1 (2), 125-144.

Hanefah, M., Ariff, M., \& Kasipillai, J. (2014). Compliance costs of small and medium enterprises. Journal of Australian Taxation, 4 (1), 73-97. 
JEMAP: Jurnal Ekonomi, Manajemen, Akuntansi, dan Perpajakan

ISSN: 2622-612X (Media Online) | Vol.4 | No.2 | Oktober 2021

Hasseldine, D., \& Bebington, KJ (1991). Blending economic standards and fiscal psychology models in design of responses to tax evasion: The new zealand experience. Journal of Economic Psychology, 12 (2), 299-324.

Hendri, N. (2016). Factors affecting taxpayer compliance in paying taxes for public service in metro city. AKUISISI Journal, 12 (1).

Imaniati, ZZ (2016). The influence of taxpayer perceptions on the application of pp no. 46 of 2013, understanding of taxation, and tax sanctions against compliance with taxpayers of micro, small and medium enterprises in the city of Yogyakarta . NOMINAL JOURNAL, V (2), 123-135.

Kartini, NKB, Yuniarta, GA, \& Sujana, E. (2017). Analysis of the level of understanding of small and medium industry taxpayers on the implementation of a self assessment system in implementing tax obligations . S1 Ak e-Journal University of Education Ganesha, 8 (2).

Lubis, USA (2015). Management of Sources of Tax Revenue as a Main Source of Funding in Development.

Mangoting, Y. (2016). Domino as a concept of tax fraud: Phenomenology study. Brawijaya University, Malang.

Mohdali. (2013). The influence of religiosity on taxpayers' compliance attitudes: Empirical evidence from a mixed-methods study in Malaysia. Accounting Research Journal, 27 (1), 71-91.

Moleong, LJ (2005). Qualitative Research Methodology. Bandung: PT Remaja Rosdakarya.

Moustakas, C. (1994). Phenomenological Research Methods. Thousand Oaks City: SAGE Publications Inc.

Mukaromah, A. (2012). Tax Interpretation and Its Implications According to the Taxpayer's Perspective of Micro, Small and Medium Enterprises. Published manuscript, Surakarta.

Mutiah, M., Harwida, GA, \& Kurniawan, FA (2011). Tax interpretation and its implications according to the taxpayer's perspective of micro, small and medium enterprises (An interpretive study). Paper presented at the National Symposium on Accounting for XIV Aceh.

Tax, DJ (2016). Performance Report.

Panggabean, H., Tirta, H., \& Muniarti, J. (2014). Local wisdom of global excellence. Jakarta: Elex Media Computindo. 
JEMAP: Jurnal Ekonomi, Manajemen, Akuntansi, dan Perpajakan

Parks, CD, \& Vu. (1994). Social dilemma behavior of individuals from highly individualist and collectivist cultures. The Journal of Conflict Resolution, 38 (4), 708-718.

Government Regulation Number 46 of 2013 concerning Procedures for Calculating, Depositing and Reporting on Income Taxes from Businesses Received or Obtained by Taxpayers with Certain Gross Circulations.

Pope, J. (2012). The effects of religiosity and external environment on tax compliance voluntary. New Zealand Journal of Taxation Law and Policy, $18,119-139$.

Rohman, A., Zulaikha, Raharjo, SN, \&Harto, P. (2011). Study of the capability of bookkeeping of small and medium enterprises (SMEs) in supporting taxpayer compliance principles. Journal of Accounting, XV (03).

Ross, ML (2004). Lead to representation does taxation? British Journal of Political Science, 34 (2), 229-249.

Sari, DP (2013). Examine the treatment of the theory of micro, small and medium enterprises. Multiparadigm Accounting Journal, 4 (2), 165-329.

Schutz, A. (1972). The phenomenology of the social world. London: Heinemann Educational Books.

Togler, B. (2002). Speaking to theorists and searching for facts: Tax morale and tax compliance in experiments. Journal of Economic Surveys, 16 (5), 657 683.

Waluyo. (2014). Indonesian taxation. Jakarta: Salemba Empat.

Welch, MR, Tittle, CR, \& Petee, TA (1991). Religion and deviance among adult catholics: A test of the "moral communities" Hypothesis. Journal for the Scientific Study of Religion, 30 (2), 159-172.

\section{Laws References}

Law No. 28 concerning General Provisions and Procedures for Taxation (2007).

Law Number 36 concerning Income Tax (2008). 